\title{
THE CONSTRUCTION OF HOMOSEXUALITY IN NEW ZEALAND JUDICIAL WRITING
}

\author{
Edward Clark*
}

This article examines the language used by New Zealand judges to describe homosexuality. It analyses the use of such language in judgments delivered after the decriminalisation of homosexual intercourse in 1986, examining the effect that judicial language has on rights claims made by homosexuals.

The article argues that a significant number of judges are careless or ill-informed in the language they use to refer to homosexuality and that the language used reinforces and repeats a number of negative stereotypes about homosexuality, constructing it as inferior to a heterosexual norm. This article criticises such careless or prejudiced language as incompatible with New Zealand's human rights commitments and argues that this language constitutes a barrier to the full enjoyment of citizenship by homosexual New Zealanders.

\section{INTRODUCTION}

In the beginning was the Word: and the Word was with God: and the Word was God. ${ }^{1}$

Words matter. Sometimes the way we choose to express something is just as important as what we say. This is because words are not neutral. Many words have the same basic meaning but come with different emotional and ideological loadings. For example, a very wealthy person could be described as a "successful businessman", a "person who earns a lot of money", or an "exploitative capitalist". The three phrases describe the same person and carry very similar core meanings, but carry positive, neutral, and negative emotional loadings respectively.

* This is a reworking of a paper submitted as part of the LLB(Hons) programme at Victoria University of Wellington. The author would like to thank Elisabeth McDonald for her supervision of the original paper and the other contributors to this issue for their very helpful suggestions during the reworking process.

1 John 1:1. 
This article is concerned with the language used by judges in their judicial writings to describe and construct homosexuality. ${ }^{2}$ It suggests that judges in New Zealand often describe and discuss homosexuality using negatively loaded language, constructing it as inferior to heterosexuality. This becomes more obvious when considering references to heterosexuality. Heterosexuality and homosexuality form a binary opposition, and heterosexuality is on the ascendant side of the binary.

In the course of researching this article, I have examined every New Zealand judgment I could find referring to or discussing homosexuality since homosexual sex was decriminalised in 1986. In all, I looked at over 150 judgments. I considered only post-decriminalisation cases because, after 1987, any negative loading in judicial language is not reinforced by criminality. Rather, the use of such language simply serves to reflect the dominant social ideology with respect to homosexuality. Before 1987, negative statements about homosexuality were condoned and reinforced by the legal system within which judges were acting, as well as by society, which somewhat confuses an analysis of judicial writing during that period.

A large portion of the judgments contained only fleeting references to homosexuality and did not reveal anything of interest, and these are not discussed. However, approximately a quarter of the judgments surveyed used language which reinforces the position of homosexuality as both inferior to heterosexuality and "other" from it - different, unusual and often dangerous.

This article will argue that the effect of such language is to undermine the sexual rights claims made by homosexual New Zealanders, thus denying them full realisation of their citizenship. As Thomas J says in Quilter $v$ Attorney-General, ${ }^{3}$ "distinctions which treat certain persons as being less worthy of concern, respect and consideration on the basis of personal differences which are irrelevant, in effect, treat them as second-class citizens." ${ }^{4}$ Much of the language analysed in this article does employ such irrelevant distinctions, intentionally or otherwise.

I do not comment on positive or neutral loading in judicial writings about homosexuality. It is entirely legitimate to expect judges to keep their personal prejudices from affecting their reasoning. As Tipping J says in Quilter, "[t]he New Zealand legislature has signalled that discrimination on the grounds of sexual orientation and gender should not be sanctioned by the Courts of this country." ${ }^{5}$ Judges need not be commended for doing nothing more than they are required to do.

2 Throughout this article the term "homosexuality" is used instead of the many other terms that could be used for non-heterosexual orientations. The reasons are twofold. First, from a purely practical perspective, using "homosexual" and its derivatives leads to consistency of terminology. Second, it is the term used most often in the judgments analysed in this article.

3 Quilter v Attorney-General [1998] 1 NZLR 523 (CA) [Quilter].

4 Quilter, above n 3, 533 Thomas J.

5 Quilter, above n 3, 581 Tipping J. 
My contention that judicial language serves to reinforce and repeat heterosexual privilege applies only to the way in which judgments are delivered, not the substance. While there have been some negative results in respect of homosexuality (particularly provocation in homicide cases), there have also been some very positive results. That is not the concern of this article and I do not as a rule comment on the results of cases.

However, as I have noted above, words matter. In particular, judges' words matter. As Bruce MacDougall points out, "[j]udicial expression influences the attitudes of the public, legislation, bureaucrats, and other judges." 6 As eminent figures in society, their words carry particular weight in defining exactly who belongs in society. No matter how positive the result is, if it is delivered in language which reinforces the inferiority of homosexuality, it serves to perpetuate the imbalance and exclusion inherent in the homosexual/heterosexual binary.

A large part of the problem with judicial expression about homosexuality is, I believe, the lack of thought that is put into the words used. As MacDougall observes: ${ }^{7}$

The tenacity of stereotypes and assumptions about homosexuals and homosexuality among the judiciary exists in large part because judges do not pause to examine ... how messages are sent in the manner of their expression as well as the ultimate decisions taken. The casualness of judicial expression is at least as much at fault in the perpetration of negative assumptions about homosexuals and homosexuality as any intentional disparagement.

This article aims to show the ways in which judicial expression can undermine an inclusive concept of citizenship, supporting the idea that heterosexuality is the desirable norm and homosexuality an undesirable deviance. It argues for the necessity of judicial caution in language and expression, and developing a neutral and accurate vocabulary to use when referring to homosexuality. I will do this by showing that judicial construction of homosexuality can and does undermine the position of homosexuals in the key areas that make up sexual citizenship.

Part II sets out the theoretical framework of sexual citizenship I use and outlines the binary construction of heterosexuality and homosexuality. Part III examines the distaste that many judges have for homosexual sex. Part IV shows that the language used in many judgments portrays homosexual identity in a negative way. Part $\mathrm{V}$ aims to demonstrate that judges often present homosexual relationships and families as problematic and necessarily inferior to heterosexual relationships.

6 Bruce MacDougall Queer Judgments: Homosexuality, Expression, and the Courts in Canada (1 ed, University of Toronto Press, Toronto, 1999) 5.

7 MacDougall, above n 6, 4 . 


\section{HOMOSEXUALITY AND CITIZENSHIP}

The relationship between sexuality and citizenship is a complex one. The term "sexual citizenship" has been used to mean many things. For the purposes of this article, I will use sexual citizenship to mean the collection of sexual rights "granted or denied to various social groups". ${ }^{8}$ For the purposes of analysis, following Diane Richardson's useful technique, I will divide sexual citizenship claims into three main streams: practice, identity, and relationship based claims. ${ }^{9}$ Practice claims involve "seeking rights to various forms of sexual practice in personal relationships (eg campaigns for sexual freedom and safety)". ${ }^{10}$ Identity claims involve "seeking rights through self-definition and the development of individual identities (eg the right to be lesbian and gay ...)". ${ }^{11}$ Relationships claims involve "seeking rights within social institutions: public validation of various forms of sexual relations (eg ... same-sex marriages)". ${ }^{12}$ These rights claims include civil and political rights, but also encompass social rights and recognition.

Using Richardson's divisions, we can examine the different ways in which the established social structures, in this case the judiciary, resist and problematise the sexual citizenship claims made by homosexuals. This article will argue that this is achieved by placing citizenship and heterosexuality on one side of a binary and constructing homosexuality in opposition to those concepts - as the opposite to heterosexuality and inimical to the civic good.

Heather Lauren Hughes, drawing on the work of Elizabeth Grosz, usefully explains the relationship between the two sides of a binary: ${ }^{13}$

The interdependence of terms in binary opposition is hierarchical, with one term consistently dominant and prior to the other. ${ }^{14}$ Feminist and philosopher Elizabeth Grosz explains: "Within these binary couples, the primary or dominant term derives its privilege from a curtailment or suppression of its opposite. Sameness or identity, presence, speech, the origin, mind, etc. are all privileged in relation to

8 Diane Richardson "Constructing Sexual Citizenship: Theorising Sexual Rights" (2000) 20 CSP 105, 107.

9 Richardson, above n 8, 107-108. Like Richardson, I found this a useful technique for analysis. However, I also echo her proviso that such division is merely an intellectual tool, and that sexual citizenship claims are often inextricably linked.

10 Richardson, above n 8, 108.

11 Richardson, above n 8, 108.

12 Richardson, above $\mathrm{n} 8,108$.

13 Heather Lauren Huges "Same-Sex Marriage and Simulacra: Exploring Conceptions of Equality" (1998) 33 Harv CR-CL L Rev 237, 248.

14 Jaques Derrida Of Grammatology (Gayatri Chakravorty Spivak trans, Johns Hopkins University Press, Baltimore, 1976) (footnote in original). 
their opposites, which are regarded as debased, impure variants of the primary term." ${ }^{15}$ Grosz's passage suggests that meaning is made through contrast: positive definitions derive their meaning from the negation of their represented opposites.

Under Grosz's analysis, established society can be seen as defining and strengthening itself by denigrating that which is outside it. Carl Stychin suggests that many contemporary concepts of citizenship are exclusive as well as inclusive, asking questions such as "who is a citizen of this community? Who is a responsible citizen deserving of the rights of members?"16 Further, Stychin argues that "rights are dependent upon evidence of the common good."17 By insisting on the normality of heterosexuality and the otherness of homosexuality, as well as reinforcing negative stereotypes, homosexuals can be constructed as irresponsible and undeserving of full citizenship.

Using these ideas of citizenship, sexual rights, and binary construction, I will examine judicial writing to show how the language used in many judgments can and does reinforce the stereotypes and ideologies that problematise rights claims from, and the full citizenship of, homosexual New Zealanders.

\section{HOMOSEXUAL PRACTICE}

The manner in which many judgments deal with homosexual sex is one of the clearest illustrations of how judicial language marks homosexuality out as inferior to heterosexuality. Although sex between males is not illegal, it is still depicted as indecent, unnatural and sterile. ${ }^{18}$ Homosexual sex is not capable of producing offspring, and thus serves no greater social purpose (as opposed to "productive" heterosexual sex). ${ }^{19}$ Claims by homosexuals for practice rights are therefore deeply problematic. Even when moral judgements are not visible in judicial decisionmaking, the language used by many judges still marks out the deviance of homosexual sex from the norm.

Even in situations where it is obvious that a particular incident of sexual activity is taking place between two people of the same sex, the reader's attention is emphatically drawn to the homosexual

15 Elizabeth Grosz "Deconstruction and Feminism: Derrida and Irigaray" (1986) 20 Intervention 70, 73, quoted in Joan W Scott "Deconstructing Equality-Versus-Difference: Or, the Uses of Poststructuralist Theory for Feminism" (1988) 14 Feminist Studies 33, 37 (footnote in original).

16 Carl Stychin Governing Sexuality: The Changing Politics of Citizenship and Law Reform (Hart, Oxford, 2003) 10 .

17 Stychin, above n 16, 12.

18 Lesbian sex, on the other hand, is largely invisible.

19 Stychin, above n 16, 11. 
nature of the activity. This technique can be seen in the following passage from $R v S$, in which the judge summarises a police interview: ${ }^{20}$

Q S by the way you are now acting I think that there is something you want to tell me is that right?

A Yes, I have not been able to sleep. That night I got up after midnight and biked around to R's

place. I was going there to get some oil from R. I did not know if he had any or not. Usually he just

goes down the road and gets it for me. When I got there I knocked on the door and R let me in.

He then described drug taking and homosexual behaviour involving himself and the deceased.

Here, sexual activity is described as "homosexual behaviour". ${ }^{21}$ It is almost impossible to find any judgment that refers to "heterosexual behaviour". ${ }^{22}$ This type of usage leads to the implication that all interactions between homosexual people revolve around sex, while the same is not true of heterosexuals. "Homosexual behaviour" could refer to two homosexual men watching a gaythemed film together as easily as it could to them having sex, yet it is only ever used in a judicial context to refer to sex.

The judiciary in New Zealand is not willing to make the same assumptions about heterosexual behaviour, revealing the heterocentric standpoint from which they write their judgments. This lends credence to the stereotypical assumption that sex plays a more important role in the lives of homosexual people than it does for heterosexual people. Heterosexuality is treated as the norm, so heterosexual behaviour does not need to be overtly flagged. Unless marked as "other", all sexual activity is assumed to be heterosexual.

The appellant in $R v S$ is identified as male. The deceased (R) is identified as male. The sex between them can be nothing other than homosexual, yet the judge feels the need to specifically draw attention to it. Such extra attention does not in any way assist the judge's reasoning or contribute to the conclusion ultimately reached in the case. The judge's insistence on the homosexuality of the sex only serves to mark homosexual sex as problematic and abnormal.

This package of assumptions is also evident in $R v R$, an indecent assault case: ${ }^{23}$

In his cross-examination he [the defendant] endeavoured to explain why he had not mentioned some of these matters in his earlier statement to the police sergeant. He made no secret of the fact that he

$20 \quad R v S$ (27 July 1998) CA 118/98, Keith J for the Court.

21 The term "homosexual behaviour" is also used in $A \& N v$ the Queen (4 June 2004) HC AK CRI-2004-292110 , para 7 Randerson J (an early interlocutory ruling in $R v$ Ali (19 August 2004) HC AK CRI-2003-2921224).

22 Indeed, I did not find any in my survey of New Zealand case law.

$23 R v R$ (30 October 1990) CA 206/90, Casey J for the Court. 
thought the complainant would be interested in homosexual activities from the moment he first saw him with the group outside the hall, acknowledging that he was bi-sexual himself.

Again, both participants are identified as male. The passage refers to possible sexual activity between the two. Again the content of any sex is referred to euphemistically, and again its homosexual nature is actively signalled. The only difference between the two is that $R v R$ uses "homosexual activities" rather than "homosexual behaviour". ${ }^{24}$

The case of $R v$ Ali includes another, particularly striking, example of this sort of overemphasis on the homosexual nature of the sex to which the judge is referring. ${ }^{25}$ The case involved the murder by a young man of a man in his fifties. The victim was a family friend of the accused. The older man had allegedly made a sexual advance towards Mr Ali, who then stabbed him. As reported in an interlocutory judgment concerning available defences, in his evidence before the jury, Mr Ali stated that he thought if he did not repel the victim, "he'll be [sic] probably rape me and all those other things." 26

When referring back to this statement later in the judgment, Williams $\mathrm{J}$ stated that Mr Ali had "feared homosexual rape."27 Not only was it obvious that this alleged fear of rape concerned two males, but in this case the accused himself made no specific reference to homosexual rape. This descriptor was added by the judge a scant eight paragraphs after he quoted the accused's evidence. It serves no purpose whatsoever, other than to draw attention to the homosexual nature of the act.

Also of note in respect of many of the usages discussed above is that the actual content of the sexual activity is not described. Instead, euphemistic, general expressions such as "homosexual behaviour" are used, allowing the judges simultaneously to signal the otherness of the act while avoiding a description of what actually happened, flagging homosexual sex as other and, implicitly, unspeakable. This type of language paradoxically both insists on the sexual nature of all interaction between homosexuality and also deprives the sex of any content.

24 The same redundant usage is present in: $R v$ Fergusson (5 December 2002) HC ROT T 02/2759, para 2 Rodney Hansen J, except that the relevant euphemism is "homosexual activity"; $R v$ Tonihi [1995] 1 NZLR 154, 155 (CA) Eichelbaum CJ, the usage being "unwanted advances of a homosexual nature"; $R v E d w a r d s$ (16 September 2004) HC AK T2003-004-025591, para 48 Frater J, $R v$ Edwards [2005] 2 NZLR 709, para 16 (CA) Chambers $\mathrm{J}$ for the Court, and the High Court sentencing judgment in $R v$ Ali, above n 21 paras 7 and 8 Williams $\mathrm{J}$, the phrase in these three cases being "homosexual advance". An earlier interlocutory judgment (concerning the admissibility of evidence of the deceased's convictions) in the $R v$ Ali series of cases also uses the phrase "homosexual motivation" when "sexual motivation" could have been used without any loss of clarity or change of meaning: $R v$ Ali \& Nadan (22 July 2004) HC AK 2003-292-1224, para 11 Williams J.

$25 R v$ Ali, above $\mathrm{n} 21$.

26 R v Ali \& Nadan (21 July 2004) HC AK CRI-2003-292-1224, para 22 Williams J.

$27 \quad R$ v Ali \& Nadan, above n 26, para 30 Williams J. 
Recently, some judges have avoided such usage. $Y v D$, a personal grievance case, concerned two male litigants, one of whom was described as pursuing "intimate sexual relations" with the other. $^{28}$ In $R v$ Sturm, an indecent assault case, the accused and the complainants (who were all male) were described as engaging in "sex" and "sexual activity". ${ }^{29}$ The judgment in $R v$ Sturm also makes reference to "oral sex" and "anal penetration". ${ }^{30}$ The judgment in this case (delivered by Anderson P) avoids both the tautology and euphemism of so many cases. However, these two cases are isolated and very recent. The majority of cases, even those contemporary with $R v$ Sturm and $Y$ $v D$, still use loaded tautologies and euphemisms to describe homosexual sex, perpetuating the view of homosexual sex as deeply problematic.

Some judgments go further than implying that homosexual sex is inferior to heterosexual sex. An example of such loaded language can be seen in Payne $v$ Police ${ }^{31}$ where Hardie Boys $\mathrm{J}$ euphemistically describes sexual interaction between two boys, aged 17 and 12, as "... the kind of indecent act which would be lawful between consenting persons over the age of 16 and which are ... quite common as part of the sexual development of young boys." 32 If he was merely describing the charge, this statement would be innocuous, but his reference to the "indecent act" is in the context of it (hypothetically) occurring between two consenting adults. Even though the "act" is legal, it is still categorised as indecent by Hardie Boys J. This moves the touchstone of indecency away from the lawfulness or otherwise of the act, and towards the homosexual nature of the act itself. Despite its recent decriminalisation, homosexuality is still being equated with indecency. As well as recalling its former illegality, describing homosexual sex as indecent carries with it the connotation of filth and unacceptability. This aligns homosexuality and indecency on the same inferior side of the homosexual/heterosexual binary, on the opposite side to citizenship.

Such language is perhaps not surprising in 1987, but it is echoed almost 10 years later by Kerr J, in the High Court hearing of the Quilter case in 1996: "It is no longer an offence for males of 16 years or over to commit indecencies with each other which are consensual." 33 Consensual sexual acts between men necessarily entail "indecencies", again stigmatising homosexual sex, a decade after this country decriminalised it. This sort of language continues to problematise the realisation of homosexual practice rights - indecencies need not be granted recognition.

\footnotetext{
$28 Y v D(15$ December, 4 March 2004), para 5 Judge Colgan.

$29 R v$ Sturm (01 June 2005) CA 28/04, paras 6 and 19 Anderson P for the Court.

$30 R v$ Sturm, above $\mathrm{n} 29$, paras 11 and 19 Anderson P for the Court.

31 Payne v Police (14 July 1987) HC TIM AP 76/87.

32 Payne v Police, above n 31, 1 Hardie Boys J.

33 Quilter v Attorney-General [1996] NZFLR 481, 491 (HC) Kerr J.
} 
As these judgments show, homosexual sex is constructed by judges as both other and as inferior. The language used by judges marks out homosexual sex as different from the norm. It also places concepts such as "indecent", "unnatural" and "infertile" on the same undeserving side of the binary as homosexual sex. Heterosexual control of full citizenship is thus reinforced and repeated by the wording of these judgments.

\section{HOMOSEXUAL IDENTIFICATION}

"At the most basic level, identity-based sexual rights claims include the right to sexual selfdefinition and the development of individual sexual identities. This is a model of sexual citizenship based upon notions of who the individual is ...."34 Rejecting the validity of identity-based citizenship claims thus strikes at the heart of how many homosexual people define themselves. ${ }^{35}$ Despite its importance to homosexual people, some judges fail to realise how deeply ingrained homosexual identity is.

The language used by the Family Court in $G v R$ frames homosexual orientation as something shameful. ${ }^{36}$ This case involved a homosexual father attempting to get access to his two daughters, who were living with their mother and her new partner. The judgment leaves the reader in no doubt that the father's sexual orientation is to be deplored. Judge Inglis QC stated that the father must bear some responsibility for the mother and her partner's hostility towards him. ${ }^{37}$

Homosexuality is depicted by the Judge as a rather trivial choice. The issue of the father's sexual orientation is dealt with under the heading: "The father's chosen lifestyle." 38 This phrase is used again to close the discussion, in which the Judge also refers to "the father's present sexual orientation". ${ }^{39}$ All these choices of wording reinforce the idea that his sexual orientation is a relatively unimportant choice the father has made because homosexuality presently interests him as a lifestyle. Such language gives scant regard to the importance of a person's sexual identity.

The language used in articulating the result of this case also reveals some ingrained assumptions. In deciding to deny the father's access request, the Judge rightly views the best interests of the children as the determinative factor. ${ }^{40}$ However, the language he uses coming to his

34 Richardson, above n 8, 117-118.

35 That sexual identity is important can be acknowledged even by those who take a constructivist view of sexuality. As Judith Butler points out, "A construction is, after all, not the same as an artifice." See Judith Butler Bodies That Matter (Routledge, New York, 1993) 94.

$36 G \vee R(1989) 5$ FRNZ 78 (FC).

$37 G v R$, above n 36, 81 Judge Inglis QC.

$38 G v R$, above n 36, 80 Judge Inglis QC.

$39 G v R$, above $\mathrm{n} 36,80$ Judge Inglis QC.

$40 G v R$, above n 36, 84 Judge Inglis QC. The "best interest" test is set out in Care of Children Act 2004, s 4. 
decision is worthy of discussion. The father submitted that if access were denied on the grounds that the mother and stepfather disliked him, then it would be "a harsh penalty" for him to bear. ${ }^{41}$ The Judge agrees with this statement, but in concluding that the father should not have access, opines "if that is a "harsh penalty" for the father, is it not one which it is his duty to accept if the children's welfare so requires?"42 This observation is legally correct; the interests of the child must come before those of the parent. However, the Judge's phraseology makes it sound like he has been punished for the dislike of the mother and stepfather by being denied time with his children.

The core of this dislike appears to be the father's sexual orientation. It is not the dislike that is framed as the main problem. The language used by Judge Inglis QC makes it clear that the father is being penalised - it is he who is responsible for the problems between the two couples. His sexual orientation has been framed by the Judge as a voluntary "preference" that has caused friction between him and the mother. The suggestion is that the father should change his sexual orientation rather than the mother and stepfather working to overcome their unease regarding the father's sexuality. Therefore, the father is being made to pay the "penalty" for the homophobia of his former wife and her partner.

A stereotype that forms a large part of the social disapproval of male homosexuality is the idea that homosexual men are more likely to be paedophiles than heterosexual men. The homosexual as predatory paedophile is a powerful example of the way in which homosexuals are portrayed as socially destructive. The assertion is, however, unsupported by evidence. Indeed, a significant amount of research points to an entirely different conclusion: most sexual abuse of children is carried out by heterosexual adult men on girls. ${ }^{43}$ Despite evidence to the contrary, some judicial writing supports the idea that homosexual men are paedophiles.

A particularly striking and overt example of the preconception that homosexuals are paedophiles comes from 1987, just after male homosexual sex was decriminalised. In $J v J{ }^{44}$ a child custody case involving allegations of abuse against the father, one passage in particular displays marked hostility towards homosexuality: ${ }^{45}$

What the father says in this case is that there is absolutely no truth in any allegation that he has in any way abused, sexually, or in any way the younger son, W. He has gone on oath to say he is not of homosexual disposition, and there is no reason why he should not, these days anyway, say whether he is

$41 G v R$, above n 36, 83 Judge Inglis QC.

$42 G v R$, above n 36, 84 Judge Inglis QC.

43 There are numerous studies supporting this proposition. See for example R K Oates "The Effects of Child Sexual Abuse" (1992) 66 ALJ 186.

$44 J v J(1987) 3$ FRNZ 33 (DC) Judge Seeman.

$45 J v J$, above n $44,34$. 
or not. It does have family consequences but there is no question of being judgmental about that issue in the normal way. Of course, obviously one has to look at it very critically in regard to any allegations involving children. That is the effect of this so called reforming legislation last year. So that it is certainly relevant in regard to any sexual abuse of children.

The first comment of interest here is that no one should be afraid to state his or her sexual orientation "these days". The meaning behind this becomes clearer when one considers that Judge Seeman refers to the Homosexual Law Reform Act 1986 as "this so called reforming legislation". The Judge does not like the more tolerant route Parliament has taken. In fact, he appears to think that society's attitude to homosexuality "these days" is something to be condemned. There is also the very peculiar comment about family consequences. He seems to be saying that while one can be socially judgemental about homosexuality, it is no longer possible to be legally judgemental about it, by virtue of the recent law reform. This presupposes that the "normal" way to judge homosexuality is as a criminal offence.

Finally, after stating that homosexuality has no negative legal consequences any more, Judge Seeman proceeds to say that homosexuality is legally relevant when it comes to issues of sexual abuse of children. As well as being contradictory, this statement also supports and repeats the stereotypical link between homosexuality and paedophilia. The entire passage reveals a deep-seated hostility towards homosexuality on the part of the Judge, as well as an idea that children are not safe around homosexual people.

A portion of Gault J's judgment in Quilter provides a further example of this idea in judicial writing. In this passage, Gault $\mathbf{J}$ gives two examples of invalid marriages involving homosexuals that are not discriminatory on the grounds of sexual orientation: ${ }^{46}$

Denial of the choice of marrying a child or someone already married could not be said to be

discriminatory on the grounds of sex or sexual orientation just because a homosexual male wants to

make such a choice.

It is unlikely to be coincidental that one of the examples put forward here is between a homosexual male and a child. The case at hand involved lesbian couples; there was no reason to bring homosexual men in as an example as he could equally have used a homosexual woman. As Thomas $\mathrm{J}$ points out in the same case, "the analogy with persons who are under age, mentally incapable, or bigamists is demeaning to gays and lesbians." 47

In his choice of example, Gault J has suggested that his hypothetical homosexual man wishes to marry a child. This also intimates that this man may also wish to have sexual intercourse with his new child spouse. Such an inference, which follows from the use of this example in such an

46 Quilter, above n 3, 527 Gault J (emphasis added).

47 Quilter, above n 3, 538 Thomas J. 
unnecessary context, reinforces the inaccurate stereotype of the homosexual man as a paedophile. Gault J's phraseology implies that there is some truth in this stereotype despite the fact that there is nothing to support it, adding "pervert" to the list of loaded adjectives that reside with homosexuality on the inferior side of the homosexual/heterosexual binary.

Payne $v$ Police provides another example of this stereotype being endorsed by a judge. ${ }^{48}$ One of the reasons Hardie Boys $J$ seems sympathetic to the appellant is that "a clinical psychologist ... found the appellant's motive [in initiating sexual acts with the victim] a mystery because he could discern no evidence of homosexual tendencies." ${ }^{49}$ In Hardie Boys J's analysis, this seems to reduce the offending to little more than "the sort of sexual experimentation that ... young boys from time to time engage in". ${ }^{50} \mathrm{Had}$ there been evidence of "homosexual tendencies", it is highly unlikely that the same degree of innocence would have been ascribed to the appellant. Heterosexuality is equated with innocence. Conversely, this logic implies that homosexuality is associated with a possible sexual interest in children and youths.

A more direct example of this prejudice is found in $T v L .^{51}$ While considering whether allegations of sexual abuse of a boy by his father were sound, Holland J states: ${ }^{52}$

I have also taken into account that the appellant and the respondent had, as a boarder in their house and have retained as a close friend, a relatively young man who, although now married, acknowledged having had a serious homosexual relationship with another adult. I have also taken into account the respondent's ready acknowledgment that the boy has a close relationship with a homosexual at the crèche which he has attended since he was aged two. I readily agree with her assertion that one cannot assume that because a person is a homosexual he is likely to be a paedophile, but all that background gave me cause for some suspicion as to the allegations. I was also concerned that the boy might be relating an incident with some male other than his father.

This passage not only displays prejudice, it is also contradictory. The Judge acknowledges that one cannot assume paedophilia from homosexuality, and then in the next breath goes on to do exactly that, imputing the suspicion of abuse on the part of the father from the family's association with homosexuals. As well as contradicting himself, it is not apparent why the Judge finds any relevance in the conduct of a former boarder and the son's crèche worker. He raises the possibility of inappropriate conduct on the part of these two people, seemingly on no other basis than that they

48 Payne v Police, above n 31.

49 Payne v Police, above n 31, 2 Hardie Boys J.

50 Payne v Police, above n 31, 2 Hardie Boys J.

$51 \quad T v L(1989) 5$ FRNZ 516 (HC).

$52 T v L$, above n 51, 523 Holland $\mathrm{J}$. 
are homosexual. The whole passage is entirely lacking in logic and seems only to demonstrate that the inherent assumptions of the Judge with respect to homosexuality have entered into his reasoning.

The passages from the judgments cited above all, to one degree or another, align homosexual and paedophile on the same, inferior, side of the heterosexual/homosexual binary. This alignment of paedophilia and homosexual identity severely undermines claims for citizenship based on sexual identity.

\section{HOMOSEXUAL RELATIONSHIPS AND FAMILIES}

It is not only individual homosexuals that are portrayed as problematic by New Zealand judicial writing. Same-sex relationships, too, are seen as a cause for concern. A significant number of judgments appear to support the contention that homosexuality is antithetical to the idea of lasting relationships. This sets up a heterosexual model as both the norm and the ideal for romantic attachment. In contrast, homosexual relationships are framed as less fulfilling, long-standing and important.

Heterosexual relationships are also seen as contributing more to society than homosexual ones, largely because of their supposed monopoly on the production of children. They are also seen as the preferred environment in which to raise those children. A significant amount of judicial language reinforces these assumptions, reinforcing the idea that homosexual relationships are less socially desirable and less worthy of recognition than heterosexual ones. ${ }^{53}$

\section{A Homosexual Relationships}

The courts mark out the difference of homosexual relationships from the norm as insistently as they do for homosexual sex. The difference of same-sex relationships from the norm is emphasised to the point of tautology. This is demonstrated in this passage from Neate $v$ Hullen: ${ }^{54}$

This arose in part it seems because the wife had decided to go to Australia with Amanda Basley, her partner, whom she met it would seem in August 1990. I should add, that Amanda Basley, with whom the wife continues to live in a lesbian relationship..

This description exhibits a similar dynamic to the way homosexual sex is depicted, though this time without the euphemisms. The wife and Amanda Basley are both clearly identified as women. They are identified as partners. A relationship between two women is necessarily a lesbian one. Yet the judge feels the need to draw attention to the lesbian nature of their relationship in the very

53 In the Families Commission's Focus on Family report, participants in same-sex relationships "suggested that their families lacked social visibility and broad social acceptance": Families Commission Focus on Families (Wellington, 2005) 52.

54 Neate v Hullen [1992] NZFLR 314, 316 (DC) Judge Evans. 
next sentence. The emphasis adds nothing to the judgment. It is purely tautological and its only purpose seems to be to mark the difference of the couple from the norm.

The same technique is demonstrated in just one sentence in $K S v L S:$ "A year after the parties' separation the mother entered a lesbian relationship with a Ms T ... ." 55 Again, both members of the relationship are identified as female, yet the Judge states that the relationship is a lesbian one. The phrases "same-sex relationship" and "same-sex de facto relationship" are similarly used in several cases where both parties to the relationship have already been clearly identified as being of the same gender. ${ }^{56}$ In contrast, the only time "heterosexual de facto relationship" appeared in a judgment was when it was used in contrast with a same sex relationship. ${ }^{57}$ I could find no other references to that or similar phrases.

Cooke $\mathrm{P}$ demonstrates the same issue as discussed above in a slightly different form in $R v$ Maly: "... he is a homosexual. His account of the events leading to the offence is that, with a homosexual lover, he and another person went on a visit to Argentina." ${ }^{58}$ Cooke P states that the appellant is homosexual and then in the next sentence we are told his lover is homosexual too. This addition is entirely redundant, as it would be surprising if the homosexual appellant had had a heterosexual lover. Yet Cooke $\mathrm{P}$ feels the need to once again mark out the otherness of the relationship and its deviance from the heterosexual paradigm.

As well as deliberately marking out homosexual relationships as deviant, the language used by judges often implies that such relationships are fleeting, inconsequential and explicitly inferior to heterosexual relationships. The case of $R v$ Cole provides a good example of this. ${ }^{59}$ In this case the Court of Appeal quashed a prison sentence against a bisexual man and replaced it with noncustodial sentence. The first reason the court gave for this was "[t]he likelihood of lasting damage to Cole if incarcerated. In this regard, we note that the doctor considers likely the provocation and entrenchment of his homosexual tendencies." 60 The second reason was the stated intention of Cole and his girlfriend to get married. ${ }^{61}$ Relying on doctor's advice, the Court finds that going to jail

$55 K S v L S$ [2003] NZFLR 817, 820 (HC) Priestley J.

56 Hildred $v$ Strong (10 November 2003) HC WN CIV-2003-485-218, para 4 Wild J; P v K [2004] 2 NZLR 421, para 4 (HC) Harrison J; Public Trust v Nicholas [2005] NZFLR 923, para 1 (HC) France J.

$57 P v K[2003] 2$ NZLR 787, para 202 (HC) Heath J.

$58 \quad R v$ Maly (12 November 1991) CA 187/91, Cooke P.

$59 \quad R v$ Cole (1988) 4 CRNZ 49 (CA).

$60 R v$ Cole, above n 59, 51 Barker $\mathrm{J}$ for the Court.

$61 R v$ Cole, above $\mathrm{n} 59,50$ Barker $\mathrm{J}$ for the Court. 
"would be likely to lead to a future pattern of fleeting homosexual relationships, with concurrent emotional upheaval, rather than to a more enduring heterosexual attachment."62

The charge against Cole was one of sexual violation of an intoxicated 14 year-old boy: not a minor offence. Yet the Court's fear of his homosexual tendencies being "provoked" and "entrenched" by incarceration was so acute that they felt the need to spare him a prison sentence. The fact that there was a possibility of "normal" heterosexual attachment (specifically, marriage), as opposed to "fleeting" homosexual ones, was also seen as important. The decision to reduce Cole's sentence therefore rests on a desire to promote a committed heterosexual relationship and discourage homosexual relationships. This reasoning assumes that heterosexuality is better than homosexuality. It valorises heterosexual relationships and marriage and denigrates same-sex ones as fleeting and emotionally unsatisfying, founded only on the sex act. ${ }^{63}$

Marriage is also figured as a society's preferred form of relationship. Stychin notes the idea that marriage is granted special status, and remains the sole domain of opposite-sex couples, because of the supposed "particular and unique contribution of heterosexual couples to the common good." 64 Even though homosexuals are not allowed access to the institution of marriage, they are seen as undermining it. The existence of homosexual relationships as a perversion of marriage can lure men who would otherwise have married into "sterile" relationships that do not contribute to society. ${ }^{65}$ If such assumptions are accepted (as they seem to be in the judgment in $R v$ Cole), the case for recognition of homosexual relationships is seriously undermined.

These ideas are further illustrated in $V P v P M,{ }^{66}$ where a mother living in a relationship with another woman is awarded custody over the father and his heterosexual partner. The terminology used for the respective partners of the parties is of particular interest here. The husband's girlfriend is consistently described as his "partner". ${ }^{67}$ The mother's girlfriend, on the other hand, is consistently described as her "friend". ${ }^{68}$ This speaks of the judge's unwillingness to acknowledge the sexual and emotional nature of the mother's relationship. It also means that he is unwilling to place the two relationships on the same level. The use of the word "friend" in place of "partner"

$62 R v$ Cole, above n 59, 50 Barker $\mathrm{J}$ for the Court.

63 See the discussion on this topic in Leo Flynn "The Irish Supreme Court and the Constitution of Male Homosexuality" in Carl Stychin and Didi Herman (eds) Legal Inversions (Temple University Press, Philadelphia, 1995) 35-36.

64 Stychin, above n 16, 11-12.

65 Flynn, above n 63, 36.

$66 \quad V P \vee P M(1998) 16$ FRNZ 621 (FC).

$67 V P \vee P M$, above n 66, 621, 623, 624, 627, 628 and 630 Judge P D Mahony.

$68 V P \vee P M$, above n 66, 624, 627 and 628 Judge P D Mahony. 
substitutes a platonic, possibly casual, relationship for the abiding sense of commitment "partner" implies.

Homosexual relationships, then, are constructed in judicial language as more fleeting and of less consequence than heterosexual relationships. Marriage is given special status as the socially preferred form of relationship. The ideas of permanence and productivity associated with it, which are constructed firmly as heterosexual ideas, privilege heterosexuality at the expense of homosexuality and question the validity of claims for recognition of homosexual relationships.

\section{B Homosexual Families}

One of the things that social conservatives worry most about is the desire of homosexuals to parent children and form their own families. ${ }^{69}$ We have seen that the language used by the New Zealand judiciary often implicitly (and sometimes explicitly) marks homosexual relationships out as other and inferior. Given this tendency, it is unsurprising that the language used to refer to the idea of homosexual parents also reinforces the heterosexual side of the homosexual/heterosexual binary at the expense of the homosexual. Several usages question the validity of homosexual parenting and families headed by homosexual couples.

The case of $K v M$ takes issue with families headed by same-sex couples. ${ }^{70}$ In his judgment Judge Inglis QC distinguishes between "the traditional nuclear family", ${ }^{71}$ headed by an opposite-sex couple, and the family in question in the case, which is headed by a same-sex couple. He says this family "may ... be a 'psychological' nuclear family."72 This indicates a belief that there can be no true nuclear family other than a traditional one. The only alternative model of a nuclear family offered is qualified by the addition of "psychological", and this term is itself problematised by the addition of quotation marks. All family units other than traditional ones are therefore implied to be problematic.

This conclusion is far from inevitable. In the Oxford English Dictionary, nuclear family is defined as "a term for the basic family unit or group, consisting normally of father, mother, and offspring." 73 Even in its most literal, dictionary definition, the traditional heterosexual family is framed only as the most common sort of nuclear family, not the only sort. Indeed, the definition specifically countenances other sorts of family unit that would fit equally validly into the meaning

69 See for example the press release from Reformation Testimony in relation to the Relationships (Statutory References) Bill: Reformation Testimony "The Relationships Bill is an Attack on God" (8 March 2005) Press Release.

$70 K v M(2002) 22$ FRNZ 360 (FC).

$71 K v M$, above n 70, 368 Judge Inglis QC.

$72 K v M$, above n 70, 368 Judge Inglis QC.

73 Oxford English Dictionary (2 ed, Clarendon Press, Oxford, 1989). 
of "nuclear family". The respective phrasing of the two family constructions by the Judge in $K v M$, however, frames the heterosexual-headed family as superior to the homosexual-headed one.

$K v M$ also suggests that homosexuals are not fit parents. During the course of his judgment, Judge Inglis QC makes this unusual statement: ${ }^{74}$

... I have also found it unnecessary to consider for present purposes any political or ideological aspects

of same-gender relationships. At a future phase of these proceedings it may become necessary to consider the extent to which any such influences may have a bearing on the quality of D's upbringing ...

I have mentioned these matters ... simply because there is no way of knowing how this case may

develop as it proceeds.

The Judge states explicitly that the effects of homosexual parents on the child are irrelevant to the case at hand. He then goes on to consider them. Both couples involved in the case are samesex, so there is no question of homosexual versus heterosexual households. It is difficult, therefore, to see at what "future stage of these proceedings" the issue of homosexuals as fit parents could come up. The reason for bringing up these points is, the judge states, because the future is unknown. With respect, this is not compelling reasoning. It seems that consideration of the sexual orientation of the parents with respect to their parenting ability is completely irrelevant to the case, unless the parenting ability of same-sex couples generally is to become an issue, in which case the child would have to be removed from the custody of both parents. This passage makes no useful contribution to the judgment. It does not affect the result. The only effect in raising it is to question the suitability of placing children with homosexual parents.

Judge Inglis QC also sees "political" aspects to same-sex relationships. This statement seems to reveal ingrained prejudice. The question the Judge neither asks nor answers is what, exactly, is the political content of a same-sex relationship. It is difficult to imagine a judge ascribing political motivation to a heterosexual relationship of the same nature as the couples in this case. Both are committed, long-term relationships. The mother and her partner are raising a child together. If this situation involved a married, heterosexual couple, it would look like a model relationship. Yet the Judge is concerned that there may be "political" and "ideological" issues surrounding these relationships. This would only be the case if Judge Inglis QC's politics and ideology found samesex relationships problematic. Thus it is the Judge's politics and ideological assumptions that are revealed by this passage, rather than anything meaningful about the couples in question. Again, it is not the Judge's beliefs that are criticised, rather the fact that they have visibly shown through in the judgment in a manner that is potentially prejudicial to the litigants who come before him.

The judgment in $K v M$ also suggests that homosexual parenting is unnatural, portraying homosexual sex as an unnatural, infertile practice. When discussing the mother's decision to use

$74 K v M$, above n 70, 365 Judge Inglis QC. 
artificial insemination to conceive, Judge Inglis QC states that "there might have been a natural reluctance on both sides to engage in the direct congress designed by nature to lead to... [the birth of a child]."75 This is an extraordinarily indirect way of saying that homosexuals do not enjoy sex with those of the opposite sex. It also refers to the fact that same-sex couples cannot reproduce without outside assistance. The most interesting point in this observation is the description of heterosexual sexual intercourse as "the direct congress designed by nature". This choice of words places heterosexual sex and heterosexual parents on the side of nature. The corollary is that homosexual sex and homosexual parents are unnatural: nature has sanctioned neither their forms of sexual intercourse nor their desire to be parents. ${ }^{76}$

The question of the suitability of homosexual parents is also raised in $G v R \cdot{ }^{77}$ As noted before, the key cause of the enmity between the parties which led to the father being denied access was his sexual orientation. The Judge framed this denial as a "penalty". The father's sexual orientation creates conflict with those around him, which in the Judge's eyes renders it unwise for him to have access to his children. Homosexuality was framed as a bigger problem than homophobia and the homophobic heterosexual couple was seen as a preferable environment to the homosexual couple. Thus, homosexuality is framed as antithetical to the care of children. Parent is placed firmly on the heterosexual side of the binary.

An issue the courts seem particularly concerned about in relation to homosexual parents is children being teased about their parents' sexual orientation. $L v R$ confronts this issue, and also questions the validity of homosexuals as parents. ${ }^{78}$ The case was the appeal of a man who had been convicted of sexually assaulting his step-granddaughter. At trial, the Judge had barred all reference to the mother's lesbianism. Counsel for the appellant submitted that this had prejudiced the fairness of the trial, as they: ${ }^{79}$

... wished to submit to the jury that the nine year old complainant was being teased by her friends about

her mother being gay and having a weird friend and that this teasing might have caused the complainant,

$75 K v M$, above n 70, 364 (emphasis added) Judge Inglis QC.

76 The same line is continued in the High Court appeal of the same case. Here, while discussing the mother's fertility, Priestley $\mathrm{J}$ states that she in not infertile, but that her sexual preferences could be more accurately described as "social infertility": $P v K$, above n 57, para 507 Priestley J. This statement reduces the mother's sexual orientation to nothing more than a form of infertility. It also implies that her sexual orientation, and therefore her "infertility", is a voluntary "preference", a choice, and that if she made the choice to have heterosexual intercourse the "infertility" could be remedied. This is an absurd conclusion, particularly considering that the case is about the mother's biological child. She has declined to have heterosexual intercourse, but has still borne a child.

$77 \quad G v R$, above $\mathrm{n} 36$.

$78 L v R(15$ December 1993) CA 240/93.

$79 L v R$, above $\mathrm{n} 78$, para 42 Holland $\mathrm{J}$ for the Court. 
in order to draw attention to herself, to make a false complaint of indecent assault by her stepgrandfather and might have explained the complainant's upset condition at the time of making the complaint.

The Court of Appeal accepted this as a plausible argument and therefore ruled that the mother's sexual orientation was relevant. Elisabeth McDonald's analysis of this passage highlights the disturbing conclusions which flow from its reasoning: ${ }^{80}$

In the absence of other evidence to support such a claim, it is of considerable concern that the Court was prepared to rule admissible this evidence, which both reinforces a belief that children can be this upset by their parents' homosexuality or lesbianism, and that such children may reflect this distress by fabricating a charge of sexual assault.

As McDonald points out, the acceptance by the Court of this argument reveals a very negative attitude towards homosexual parents impliedly questioning the fitness of all homosexual parents to raise their children.

This concern about teasing is also seen in Neate $v$ Hullen, where one of the Judge's concerns about placing the child in question with the lesbian mother "is that Stephanie has been teased at school in relation to that [lesbian] relationship." ${ }^{81}$ Both cases treat the teasing of children about their parents' sexual orientation as a significant problem. Judge Green in $B v P$ demonstrates what I would suggest is a better, more balanced way of looking at the issue. ${ }^{82}$ The case involved a custody dispute between a lesbian mother and the parents of her late husband, who had committed suicide. When commenting on the question of teasing, the Judge said: ${ }^{83}$

There is a risk that a child living in a family that differs from the norm may at some stage be the subject of taunts, however such taunts may just as easily focus on his father's suicide if he is to remain with the Ps.

As the Judge notes here, what induces teasing among young people is difference from the norm, not specifically the sexual orientation of their parents. Thus a child could be subject to teasing because one or more of the adults in their life is an amputee, or has a speech impediment, or belongs to an ethnic minority, all of which are groups that do not belong to the New Zealand "norm". It is doubtful whether any court would criticise the parenting of any adult with these characteristics if their child had been subject to teasing at school. Yet it seems that many judges see it as a legitimate

80 Elisabeth McDonald "Gender Bias and the Law of Evidence: The Link Between Sexuality and Credibility" (1994) 24 VUWLR 175, 187.

81 Neate v Hullen, above n 54, 322 Judge Evans.

$82 B v P[1992]$ NZFLR 545 (DC).

$83 B v P$, above n 82, 547 Judge Green. 
area of comment when it comes to homosexual parents. Again we see negative ideological assumptions about homosexual parents that are not applied to other parents, simply because they are homosexual. The heterosexual family model is reinforced as the socially preferred form of family.

\section{The Importance of Discretion}

Homosexual parents and families can avoid the detailed scrutiny and criticism of their sexual orientation described above, but must be discreet. The courts compliment and reward parents who are not open about their homosexuality. This is demonstrated in $V P v P M{ }^{84}$ In deciding that the mother's home is an appropriate environment to place children, the Judge held that: ${ }^{85}$

... good parenting in the particular family circumstances may be the determining factor and the reason why the Court need not be concerned in a particular case for the wellbeing of children living in the fulltime care of a mother in a lesbian relationship. In my view that is the case here. The mother is a very gentle, discerning and prudent person. She is also very discreet.

The Judge places the children with the mother because her parenting skills are good. He also makes sure to include discretion as an integral part of these skills. Had she not been so discreet about her sexual orientation, the Judge would arguably not have seen her as such a good parent. Given the attitude to homosexuals demonstrated in the other cases discussed, it is likely that the court would be concerned about placing children with the mother had she been vehemently and openly homosexual.

This result can be contrasted with the decision in $G v R$, discussed above. In that case, the father is criticised for drawing attention to his homosexuality through making his partner "a constant presence both in ... [his] ... home and in access negotiations, so emphasising and drawing attention to the nature of their relationship." ${ }^{16}$ This is despite the fact that the father's partner was said to be "a moderating and calming influence." ${ }^{187}$ No such criticism is levelled at the mother for having her partner present in either her home or the access negotiations, even though the stepfather is described as a very direct person who was openly hostile to the father, and who the Judge implied might well be bigoted. ${ }^{88}$

Even though the Judge appears to view the stepfather less sympathetically on a personal level, the father's partner is still criticised, as he represents a public and unashamed statement of the father's homosexuality. This implies that the father should have been discreet about his new

\footnotetext{
$84 V P \vee P M$, above n 66.

$85 V P \vee P M$, above n 66, 630 Judge P D Mahony.

$86 G v R$, above n 36, 81 Judge Inglis QC.

$87 G v R$, above n 36, 81 Judge Inglis QC.

$88 G v R$, above n 36, 81 Judge Inglis QC.
} 
relationship. Thus, the judgment in this case treats homosexuality as something to be hidden, as opposed to the mother's "normal" heterosexual relationship, which is permitted to be open. The heterosexual relationship is explicitly drawn as superior to the homosexual one, and as the superior environment in which to bring up children.

\section{Summary}

The topics of homosexual families and relationships are particularly unsettling to the homosexual/heterosexual binary. The idea of marriage as the basic social unit and the ideal environment to raise children is challenged by possible recognition of homosexual families. The dominant ideology reinforces the idea of the family as a heterosexual institution and, as such, denigrates the concept of the homosexual family. Likewise, parenting is conceptualised as a heterosexual trait. These assumptions are reflected in the judicial writing discussed above. Homosexual relationships and families are portrayed as inferior, fleeting and sterile in comparison to heterosexual ones. As with practice and identity claims, careless and ignorant judicial writing gives official sanction to the idea that homosexual relationships are not deserving of civic recognition.

\section{CONCLUSION}

This article has surveyed a wide range of cases over a long period of time and at various levels. Ingrained prejudices are reflected and repeated by the writings of judges across all of these. Further, even with the large amount of reforming legislation over the last 20 years, ${ }^{89}$ the same sorts of stereotypes and assumptions seen in judgments from the late 1980s and early 1990s are also present in judgments written in the last five years. Similarly, even as full homosexual citizenship begins to be realised, judicial language continues to impliedly question its validity.

Judicial language today reveals the same ingrained ideological assumptions it did before decriminalisation. Homosexual sex was framed as "indecent acts" in Payne v Police in $1987 .{ }^{90}$ It had moved to "indecencies" by the time of the High Court Judgment of Quilter in 1996. ${ }^{91}$ By 2002 and $P v K$ it was a form of "social infertility". ${ }^{92}$ The same insistence on marking out homosexuality and homosexuals that was present earlier in cases such as $R v R$ persists today in judgments such as $R v$ Ali. Heterosexuality is still privileged by judicial language and homosexuality is still denigrated.

89 For example the Homosexual Law Reform Act 1986, the Human Rights Act 1993, the Property (Relationships) Act 1976, the Civil Union Act 2004 and the Relationships (Statutory References) Act 2005.

90 Payne v Police, above n 31, 1 Hardie Boys J.

91 Quilter v Attorney-General, above n 33, 491 Kerr J.

$92 P v K$, above n 57, 507 Heath $\mathrm{J}$. 
The situation will only change very slowly unless positive action is taken. The unfortunate fact is that judges appear unwilling to let go of their assumptions. I found only one example of an adjudicator willing to openly admit that his assumptions were wrong. In $L v M L t d,^{93}$ an Employment Tribunal decision involving discrimination on the grounds of sexual orientation, the adjudicator stated: ${ }^{94}$

[I have] had to reconsider my own value base concerning matters of sexual orientation in the area of sexual harassment, having regard to the case law and articles which have been provided to me, and also the evidence of all witnesses.

This one adjudicator was willing to abandon his standpoint and change his views when his assumptions about homosexuality were proved wrong. It is concerning that there are no similar admissions from judges in any higher courts. Without a more widespread willingness from judges to acknowledge their assumptions and change the way they construct homosexuality, hostility towards homosexuals will remain a significant problem.

Further, relying on individual judges to leave their prejudices at the door is no comfort for those people who come to court and are confronted with a judge who has no appreciation of them and their issues, and no language to describe them fairly. The frustration of homosexuals at this uncertainty can be seen in a comment by one of the contributors to the Law Commission's report on lesbian access to justice: "I mean ... this thing about the outcome of your Family Court case depends on which judge you get - I mean apparently that's rational? ... people shouldn't bring their prejudices in." 95

Judges as a group must become aware of the effect their words have on homosexual litigants and on society's perception of homosexual people generally. Such language gives official sanction to prejudice against homosexuality and undermines homosexual New Zealanders' attempts to gain full recognition of their rights by society. Further, the passage of legislation such as the Human Rights Act 1993 and the Property (Relationships) Act 1976 signals that Parliament does not countenance discrimination or differential treatment on the basis of sexual orientation. In using the language discussed in this article, judges are also frustrating the will of Parliament.

Rather than the careless and occasionally ignorant language that the survey I have conducted has revealed, the judiciary should strive to use language which does not problematise the full citizenship that homosexuals have the right to enjoy. I am not arguing for "politically correct", falsely positive Newspeak, but rather for a coherent and consistent construction of homosexuality that exists on the

$93 \quad L v M$ Ltd [1994] 1 ERNZ 123.

$94 L v M L t d$, above n 93, 127 D E Hurley.

95 New Zealand Law Commission Report to the Law Commission on Consultation with Lesbians for the Women's Access to Justice Project (Wellington, 1997). 
same footing as other identifiable social groups within New Zealand society that come before the courts - religious groups and the commercial community, for example. ${ }^{96}$

Until we see such a conscious change, ideological prejudice towards homosexuality will be reinforced and repeated every time a careless word is uttered by a judge, and every time a judge allows stereotype rather than the facts of the case to dictate his or her choice of language. Unless this happens, homosexual New Zealanders will be denied the unbiased judicial system that is their right as citizens, and thus denied full realisation of that citizenship. They will be left "knocking on the door of a heterosexual court asking for its benevolence." 97 Such a programme of linguistic reform is not the whole solution but it is a step, and an important one. Words matter.

96 MacDougall, above n 6, 5.

97 MacDougall, above n 6, 4. 
